\title{
Development of Power Assist Suit \\ - Improvement of waist and leg units -
}

\author{
○正 石井 峰雄（神奈川工科大） \\ 正 兵頭 和人（神奈川工科大） \\ 正 山本圭治郎（神奈川工科大） \\ 若井 良友（神奈川工科大）
}

Mineo ISHII, Kanagawa Institute of Technology, Shimo-ogino 1030, Atsugi-shi, Kanagawa 243-0292

Keijiro YAMAMOTO, Kanagawa Institute of Technology

Kazuhito HYODO, Kanagawa Institute of Technology

Yoshitomo WAKAI, Kanagawa Institute of Technology

New power assisting suit consisting of shoulders, arms, a back, a waist、 a hip and legs units was developed. The hip unit has the direct drive pneumatic actuator assisting the rotation of hip joints and has joints which realize the external rotation of legs. The new suit combined the hip unit transmitted assisting torque directly to each joint, especially independently to the waist joints and to the hip joints of the wearer, so that the wearer could walk easily keeping weight in the hands, and by wearing the suit the weight could be lifted by half or less muscular power. Sensor

Key Words: Power Assist Suit, Wearable, Direct Drive Pneumatic Actuator, Embedded Microcomputer, Muscle Hardness

\section{A1. 緒言}

介護者が直接体に装着することによって、簡便に肉体的 負担を軽減できる完全に独立したウェアラブルなパワーア シストスーツの開発を進めている。本研究では、スーツ着 用者の足の外旋動作を可能にするための脚ユニットの外旋 機構と歩行動作を容易にするための腰ユニットの股関節ア シスト機構を開発している。試作機の動作実験により、そ の有効性が実証されたので以下に結果を報告する。

\section{A2. 腰関節および股関節ユニット}

Fig.A1 に示すように、従来 1 つの関節でまかなっていた 腰ユニットを腰関節と股関節との $2 つ に$ 分離し、腰関節と 股関節それぞれに独立してアシスト力を伝える為のアクチ ユエータを配置した。腰ユニットを腰関節と股関節との間 に脚の外旋を可能にする回転軸を配置した。

腰関節と股関節に独立してアシストカが働くようにアク

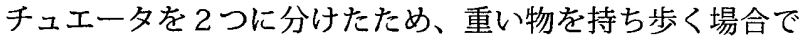
も荷重を腰関節アクチュエータで支えたままで、脚を引き 上げる動作を妨げないよう、股関節のアシスト力を独立に 制御することが可能な機構となった。

\section{A3. 結果}

開発したユニットを組み込んだパワーアシストスーツを着用し て、20Kgの鉄板を持ち、しやがんだ状態から鉄板を持ち上げ、 保持し、再びしやがんで降ろす状態に戻るまでの、膝関節角度、 大腿直筋の筋肉硬さ、膝アクチュエータ内空気圧を測定した結 果をFig. A2 に示す。新機構の効果を見るために、従来のパ ワーアシストスーツの機構で同様の実験を行った結果を Fig. A3 に示す。これらの結果を比較することにより、従来 のパワーアシストスーツの機構の方が、筋肉硬さセンサの出力 值が大きく出ており、より大きな力を出していることが明らかとな
った。この結果から新たに開発した腰および脚ユニットの有用 性が実証された。
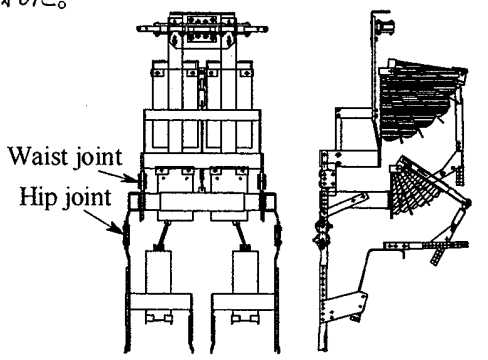

Fig.Al New waist and hip joint units

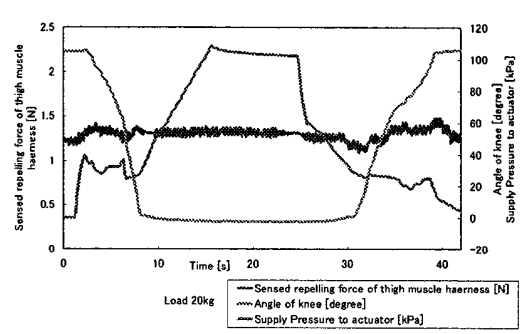

Fig.A2 Operation characteristics of new suit with new waist and hip units

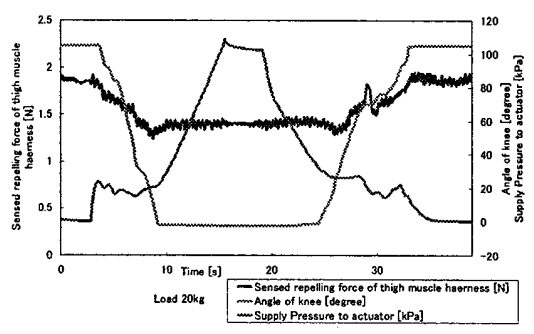

Fig.A3 Operation characteristics of suit without hip unit 


\section{1. 緒 言}

移乗介護支援を目的としたロボットの研究は、1970年 代から研究が始められ、メルコング ${ }^{1)}$ はその代表例であり、 また、マスタ・スレーブ方式による操作ロボット Nurcy ${ }^{2)}$ が開発されたが、いずれも実用の見通しは立っていない。 近年、支援機器の開発研究が活発になり、介護者の腰の 負担を軽減する移乗介護補助装置 ${ }^{3)}$ や抱き上げ補助装置 4)が提案されている。いずれもモータを用いている。また、 歩行支援を目的としたモータとボールネジを用いた外骨 格脚 5)や空気圧アクチュエータを用いた立ち上がり装具 6)が開発されている。

我々は、介護者が体に装着することによって簡便に肉体 的負担を大幅に軽減できるパワーアシストスーツを 1991 年に提案し 7)、ウェアラブルなアシストスーツを開発した 8)。その後パイプレス化・ワイヤレス化を進め、小型エア ポンプと排気バルブ、Ni-Cd 電池、执よび組み达みマイク ロコンピュータを採用することにより、完全ウェアラブル 化を実現した ${ }^{9-16) 。}$

これまでに開発したパワーアシストスーツは脚を開いてしゃが むといら動作が構造的に出来なった。しかし、脚を開いてしやが むといら行為は人が重い物をしゃがんで持ち上げようとする時に 自然に行う行動である。

本報は、スーツの機構改良を目的として、足の動作を容 易にする為の脚ユニットの外旋機構と歩行動作を容易にす る為の腰ユニットの股関節アシスト機構を開発した (Fig.A1)。試作機の機能と特性を実測し、その有効性を実 証した結果について報告する。

\section{2. パワーアシストスーツ}

Fig.1 に示す様に、アシストスーツは外骨格型で、肩、腕、 背骨、腰、股、足部からなり、肘、腰、股、膝関節部に空 気圧カフ式アクチュエータが取り付けられている。構造物 が介護者の前面を覆うことのない構造で、構造材はアルミ 系である。

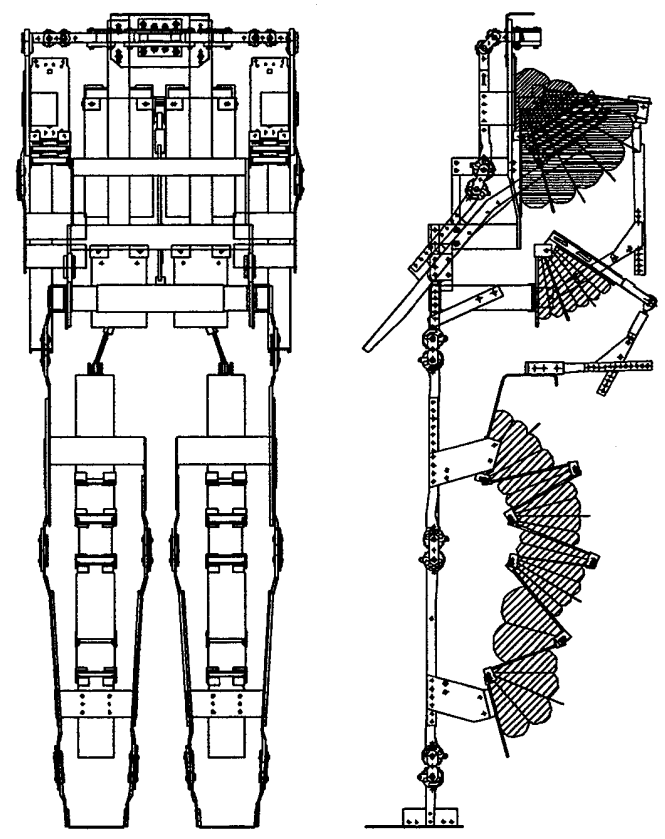

Fig.1 New power assist suit
3. ウェストユニット

パワーアシストウエストは腰関節の負担を軽減するため上半 身を引き上げることによって腰関節の動きを助ける構造を持つ。 Fig.2 に新しいウェストニニットの構造を示す。アクチュエータの 出力を上半身に有効に伝えるため 4 節リンクを利用している。胴 体部にはベルトにより拘束する方式を採用している。ウエスト部 関節の可動範囲は $0^{\circ} \sim 72^{\circ}$ である。

ウェストユニットの出力特性を Fig. 3 に示す。ここで、アクチュ エータが最も閉じた状態の角度を $0^{\circ}$ としている。線形特性を 持ち、且つ、时用や後述の膝用のアクチュエータとは異なり、回 転角度により勾配が大きく異なる特性は見られない。これはカ> を挟む薄板の一端のみ繋いでいるためである。
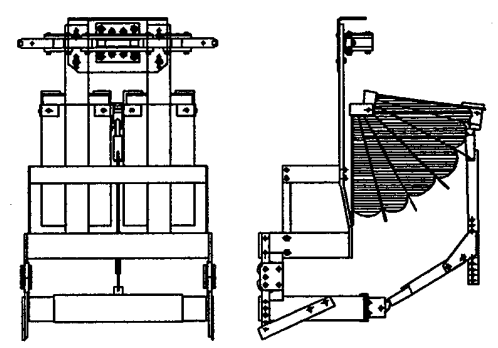

Fig.2 New waist unit

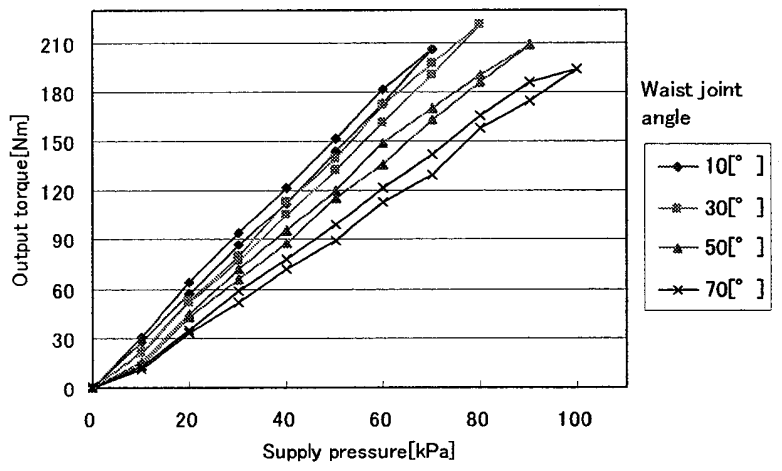

Fig. 3 Output toque vs. supply pressure characteristics of new waist unit

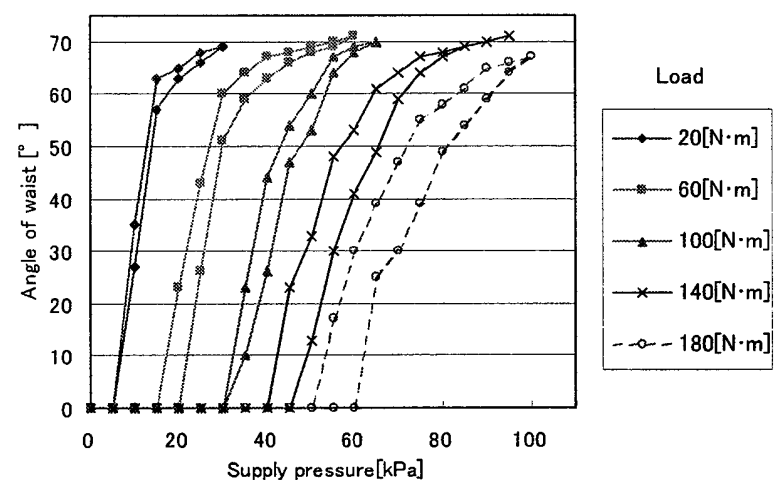

Fig. 4 Rotary angle vs. supply pressure characteristics of new waist unit

ウェストユニットの回転角度対供給圧力特性を Fig.4に示す。 負荷トルクが大きいほど勾配が緩くなる特性を示している。 


\section{4.ヒップユニット}

パワーアシストヒップユニットの構造図を Fig.5 に示す。また、 外旋機構構造をFig. 6 に示す。ヒップユニットには股関節とそ のアクチュエータ、および脚を開くための外旋関節からなる。ア クチュエータの出力を上半身に有効に伝えるため 4 節リンクを利 用している。ユニットを幅の広いベルトで胴体部に拘束する方 式を採用している。股関節の可動角度範囲は $0^{\circ} \sim 45^{\circ}$ 、外 旋関節の可動範囲は $0^{\circ} \sim 20^{\circ}$ である。

ヒップユニットの出力特性を Fig.7 に示す。ここで、アクチュエ 一タが最も閉じた状態の角度を $0^{\circ}$ としている。同じ構造を持つ ウェストユニットと同様に線形特性を持ち、回転角度により勾配 が大きく異なる特性は見られない。

ヒップニニットの回転角度対供給圧力特性を Fig.8 に示す。 ウェストユニットと同様に負荷トルクが大きいほど勾配が緩くなる 特性を示している。

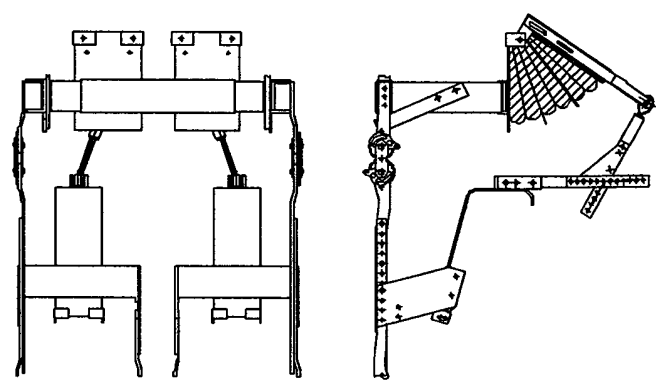

Fig. 5 Hip unit

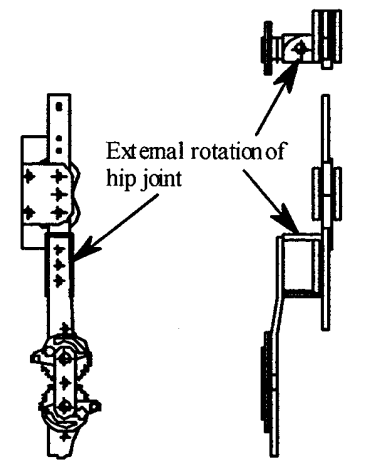

Fig. 6 Joint for external rotation of leg

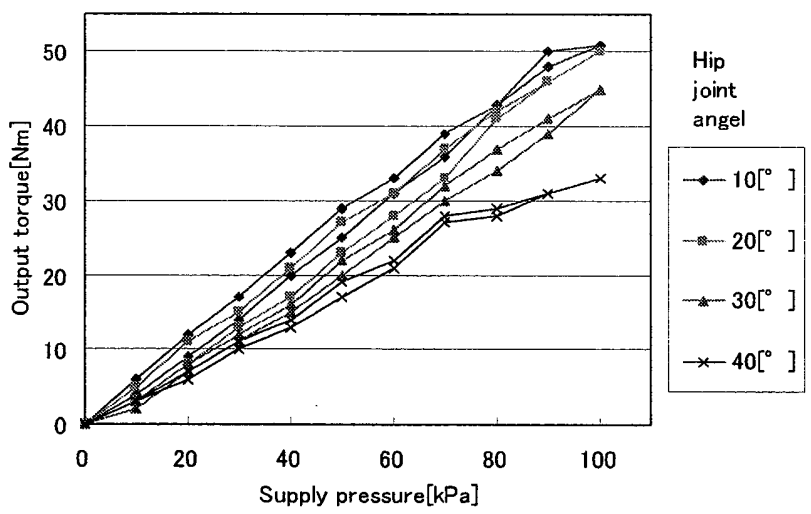

Fig. 7 Output toque vs. supply pressure characteristics of hip unit

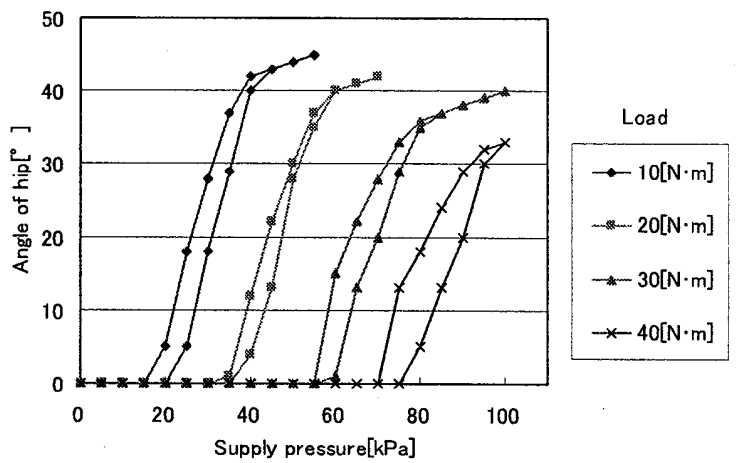

Fig. 8 Rotary angle vs. supply pressure characteristics of hip unit

$$
\text { 5.レッグユニット }
$$

パワーアシストレッグの構造を Fig.9 に示す。レッグュニット は抱き上げ時の屈伸動作の補助と歩行動作を行なえる構造を 持つ。アクチュエータのすべてのヒンジの閒にセパレータを配 置することにより、カフの横ずれを防止し、アシストカの増加を 図っている。大腿部、下腿部、足底の足への固定は布ベルトに よる方式を採用している。膝関節の可動範囲は $0^{\circ} \sim 95^{\circ}$ とし ている。

レッグニニットの出力特性を Fig.10 に示。ここで、アクチュエ 一タが最も閉じた状態の角度を $0^{\circ}$ としている。レッグユニット用 のアクチュエータはウェストユニット用やヒップュニット用のアク チュエータとは異なり、回転角度により勾配が大きく異なる特性 を持っている。これはカフを挟む薄板をジグザグに繫いでいる ため、回転中心が一点ではないためである。

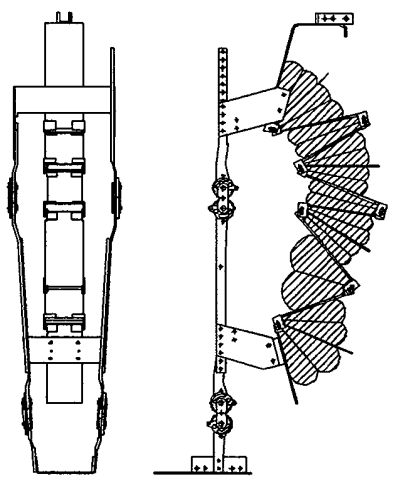

Fig.9 Leg unit

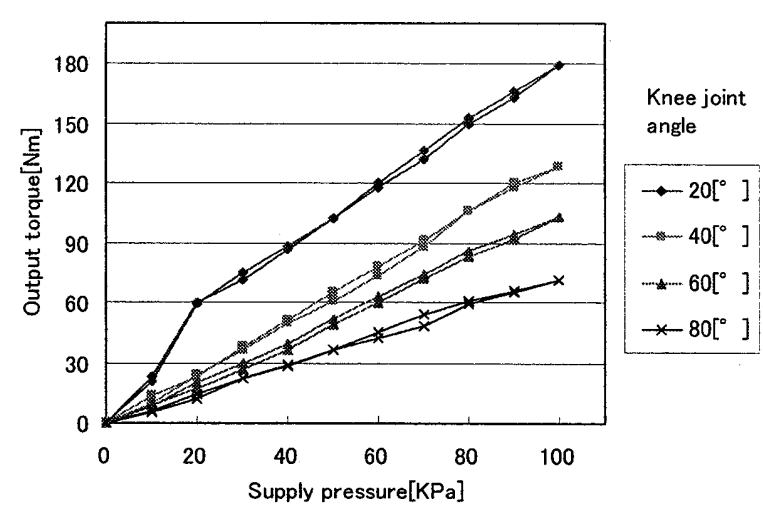

Fig. 10 Output toque vs. supply pressure characteristics of leg unit 


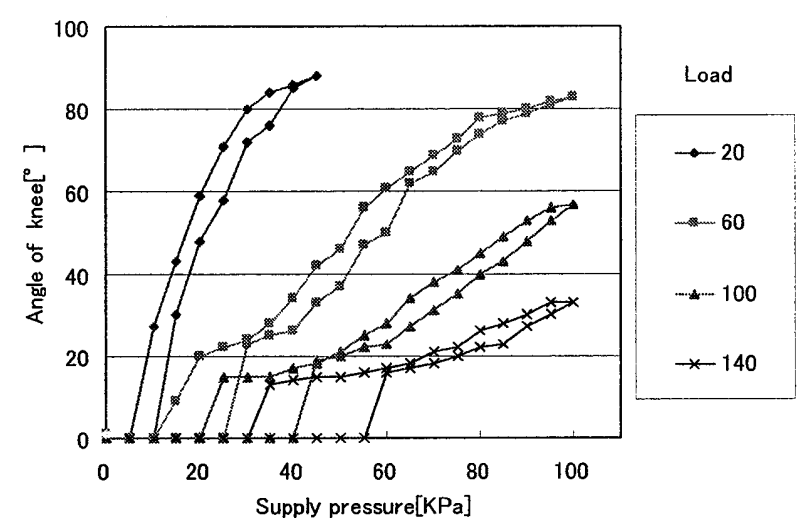

Fig. 11 Rotary angle vs. supply pressure characteristics of leg unit

レッグニニットの回転角度対供給圧力特性を Fig.11 に示す。 ウェストユニットやヒップュニットと同様に負荷トルクが大きいほど 勾配が緩くなる特性を示している。

\section{6. ユニットの動作特性}

新たに開発したユニットを組み込んだパワーアシストスーツを 着用して、前腕に $20 \mathrm{Kg}$ の鉄板を持ちしやがんだ状態から重り を持ち上げ、保持し、再びしゃがんだ状態に戻るまでの、膝関 節角度、大腿直筋の筋肉硬さ、膝アクチュエータ内空気圧を測 定した。結果を Fig.12 に示す。また、従来のスーツと比較する 為に外旋の関節と腰関節を固定して擬似的に従来のパワーア シストスーツの機構にして、同様の実験を行った結果を Fig.13 に示す。

両者を比較すると、新たに開発したユニットを組み込んだパ ワーアシストスーツを着用した場合の方が、筋肉硬さセンサの 出力值が小さく出ていることから、より少ない力で動作をしてい ることが分かる。このことは、新たに開発したウェストユニットとヒッ プユニットが有効であることを実証するものであると考えられる。

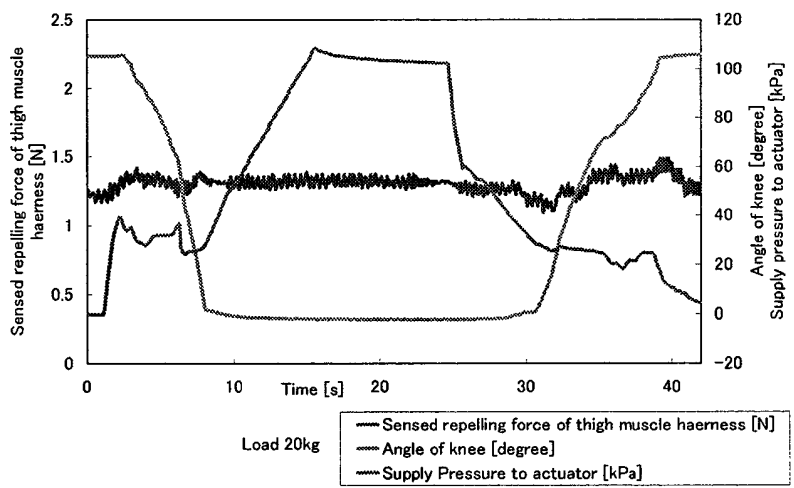

Fig. 12 Operation characteristics of new suit with new waist and hip units

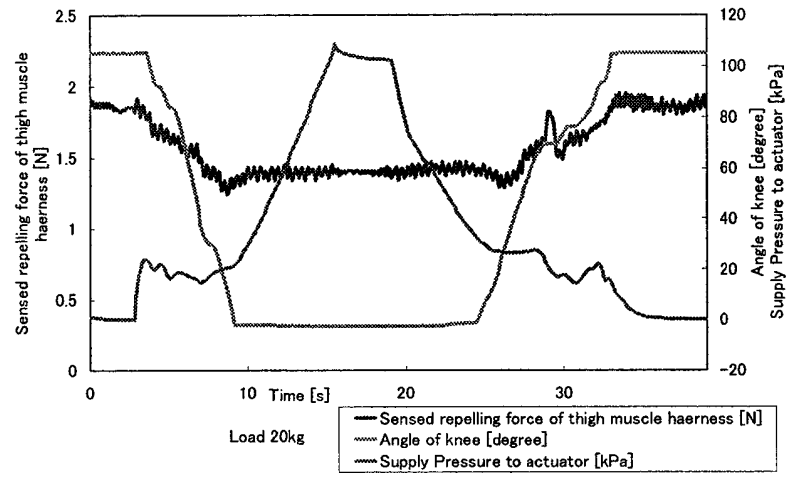

Fig.13 Operation characteristics of suit without hip unit

\section{7. 結 言}

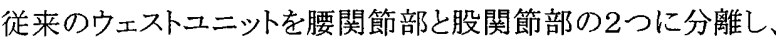
アクチュエータをそれぞれ取り付けたウェストニニットとヒップュ ニットを新たに開発した。さらにこれらの間に脚の外旋を可能 にする回転軸、外旋関節を設けた。

これにより腰関節と股関節にアシストカを独立して働か せる事が可能になり、重い物を持ち歩く場合でも荷重を腰 関節アクチュエータで支えたままで、股関節のアシストカ を下げることが可能となった。即ち、脚を引き上げる動作 を妨げないよう、アシストカを腰関節に伝えることが出来 る機構が実現されたことになる。

これら新しく開発したユニットを組み込んだパワーアシ ストスーツは、着用者の脚の動きによく追従し、且つ、十分な アシストカを発揮できた。

\section{引用文献}

（1）橋野賢、移乗介助ロボットの現状と課題、日本ロボット学 会誌、 $11,5,649,1993$

（2）岡崎勉、高橋隆、長澤亭、山下安雄、看護介助ロボットの 知能化一開放型 Prolog 処理系について、医用電子と生体工 学、24, 特別号、443、1986

（3）手嶋教之、簡易型移乗介護補助装置の開発、1998 年度精密 工学会学術講演会講演論文集、612、1998

（4）小山猛、山藤和男、田中孝之、介護用装着型ヒューマン・ アシスト装置に関する研究、日本機会学会論文集（C 偏） 66,65 1、p. 3679、2000

(5) 0kamura, J., Tanaka, H. and Sankai, Y., EMG-based Prototype Powered Assistive System for Walking Aid, Proc. ASIAR' 99, pp. 229-234, 1999

(6) Kawamura, S., Yonezawa, T., Fuj imoto, K., Hayakawa, Y., Isaka, T. and Pandian, S.R., Development of an active orthsis for knee motion by using pneumatic actuators, Proc. ICMA2000, 0saka, pp. 615-620, 2000

（7）山本圭治郎、宮西秀樹、今井政行、パワードアーム用空気 圧アクチュエータの開発、平成 3 年秋期油空圧講演会 $(\mathrm{J}$ HPS ) 、pp. 85-88、1991

（8）山本圭治郎、兵頭和人、石井峰雄、松尾崇、介護用パワー アシストスーツの開発、日本機会学会論文集（C 編）、6 7 巻65 7 号、pp. 1499-1506、2001 
(9) Yamamoto, K., Ishii, M. Hyodo, K., Yoshimitsu, T and Matsuo, T.: Development of Power Assisting Suit for Assisting Nurse Labor -Miniaturization of supply system to realize wearable suit--, JSME International Journal, Series C, Vol.46, No.3, pp.923-930, 2003

(10) K. Yamamoto, M. Ishi i, K. Hyodo, T. Yoshimitsu and T. Matsuo, Development of Wearable Power Assist Suit, Proc. of the $7^{\text {th }}$ Trienial International Symposium on Fluid Control, Measurement and Visualization, CD-ROM, 2003

（11）山本主治郎、石井峰雄、兵頭和人、吉満俊拓、高橋勝美、 松尾崇、“パワーアシストスーツの特性”、日本機械学会 Dynamics and Design Conference 2003 CD-ROM 講演論文集、 555, 2003

(12) Kei j iro Yamamoto, Mineo Ishi i, Hirokazu Noborisaka and Kazuhito Hyodo, Stand Alone Wearable Power Assisting Suit - Sensing and Control Systems-, Proc. of the 2004 IEEE International Workshop on Robot and Human Interactive Communication, 661-666, 2004

(13) Mineo Ishii, Kei j iro Yamamoto, and Kazuhi to Hyodo, Stand Alone Wearable Power Assisting Suit - development and availability-, Proc. of the $4^{\text {th }}$ International Conference on Advanced Mechatronics, JSME, 480-486, 2004

（14）石井峰雄、山本圭治郎、兵頭和人、松尾崇、高橋勝美、“介 護者用パワーアシストスーツの開発一センシングシステム およびメカニズムの改善—”、日本機械学会第 4 回福祉工 学シンポジウム講演論文集、1 $23-126 、 2004$

（15）石井峰雄、山本圭治郎、兵頭和人、松尾崇、高橋勝美、“吋 エアラブル・パワーアシストスーツのアシスト特性”、日 本機械学会 Dynamics and Design Conference 2004 講演論 文集、CD-ROM、Paper No.743、2 004

（16）高橋勝美、坂元孝子、石井峰雄、山本圭治郎、兵頭和人、 松尾崇、“パワーアシストスーツ着用による身体動作特性”、 第2 5 回バイオメカニズム学術講演会論文集、177-1 $80 、 2004$ 